\title{
Physicochemical and Sensory Properties of Wine Produced from Blended Cactus Pear (Opuntia ficus-indica) and Lantana camara (L. camara) Fruits
}

\author{
Zenebe Tadesse Tsegay (iD ${ }^{1,2}$ and Kidu Mezgebe Gebremedhin ${ }^{2}$ \\ ${ }^{1}$ College of Dryland Agriculture and Natural Resources, Department of Food Science and Post-Harvest Technology, \\ Mekelle University, P.O. Box 231, Mekelle, Ethiopia \\ ${ }^{2}$ College of Natural and Computational Science, Department of Chemistry, Aksum University, P.O. Box 1010, Aksum, Ethiopia
}

Correspondence should be addressed to Zenebe Tadesse Tsegay; ztlovewith73@gmail.com

Received 8 August 2019; Accepted 8 November 2019; Published 7 December 2019

Academic Editor: Jesús Lozano

Copyright (c) 2019 Zenebe Tadesse Tsegay and Kidu Mezgebe Gebremedhin. This is an open access article distributed under the Creative Commons Attribution License, which permits unrestricted use, distribution, and reproduction in any medium, provided the original work is properly cited.

\begin{abstract}
Blending different fruits as well as adding medicinal herbs improves important physicochemical and sensorial properties of fruit wine. The present study aimed at investigating prominent physicochemical and sensory properties of wine produced from cactus pear and Lantana camara fruit juice blend. Both fruit juices were characterized based on $\mathrm{pH}$, sugar, titratable acidity, total phenol, and organic acid contents. The fermentation process was made at previously optimized fermentation temperature of $24.8^{\circ} \mathrm{C}, \mathrm{pH}$ of 3.4 , inoculum concentration (Saccharomyces cerevisiae) of $10.16 \%(\mathrm{v} / \mathrm{v})$, and Lantana camara fruit juice concentration of $10.66 \%$ $(\mathrm{v} / \mathrm{v})$. The final wine was characterized as having $\mathrm{pH}$ of $3.47 \pm 0.04,4.6 \pm 0.02 \mathrm{~g} / \mathrm{L}$ sugar equivalent to dextrose, $0.33 \pm 0.006 \%$ titratable acidity (w/v citric acid), total phenol of $696.1 \pm 22.1 \mathrm{mg} / \mathrm{L}$ equivalent to gallic acid, and $4.35 \pm 0.4 \mathrm{mg} / \mathrm{mL}$ organic acid equivalent to citric acid composition. Predominant color intensity, ethanol, methanol, total sulfite, and sensory value of the final wine were measured as $48.07 \pm 2.66 \%$ of yellowish color, $8.6 \pm 0.68 \%$ (v/v), $124.4 \pm 9.5 \mathrm{mg} / \mathrm{L}, 129.94 \pm 4.04 \mathrm{mg} / \mathrm{L}$, and $8.65 \pm 0.92$, respectively. The blended Lantana camara fruit enhanced total phenol, color, and sensory value of the final wine. Titratable acidity and methanol and sulfite contents of the final wine are in an acceptable limit compared to standards for commercial wines. Utilizing cactus pear fruit by incorporating Lantana camara fruit for health-enhancing functional food development such as fruit wines could solve the current postharvest loss of both fruits and be a means of alternative beverage.
\end{abstract}

\section{Introduction}

Fruits are nature's marvelous gift to the human kind as they possess life-prolonging and protecting components. Fruits provide energy, vitamins, minerals, and phytochemicals; their regular consumption improves the physiological functions and reduces the risk of various diseases [1-3]. Health-enhancing functional foods such as fruit wines recently increased public interest for the well-being of life. Many studies on health-enhancing functional fruit wine developments have revealed the possibilities of blending medicinal plants with fruit juice, mixing different fruits, co-fermenting grape must and kiwifruit juice, adding ball-milled achenes to strawberry fruit substrates, and adding ginger extract to watermelon fruit juice for value-added wine production [4-9]. Phenolic compounds such as flavonoids (anthocyanins, flavanols, flavonols, etc.), betalains (betaxanthins and betacyanins), organic acids, and nonflavonoids (derived from cinnamic and benzoic acids), which have efficient antioxidant, anticancer, and antimicrobial activities, are present in fruit wines [10-15]. Several studies have reported on the antidiarrheal activity of the aqueous stem extract, antidiabetic potential of ursolic acid, antimicrobial properties of leaf extracts, and antibacterial properties of berry extracts of Lantana camara [16-18]. According to the study reported by Carstairs et al. [19], the Lantana camara fruit berry has no associated health effect during human consumption. In Ethiopia, Lantana camara plant is popularly recognized as an ornamental garden plant and is used in folk medicine (antidiarrheal and antifungus) [18]. However, using matured Lantana camara berry for food 
product is limited which could be due to the fact that physicochemical properties of this perishable fruit berry juice have deficient literature. Fermented cactus pear fruit juicederived foods are rising globally due to its potential for nutraceutical usage, preventing oxidative stress and cancer, and preventing obesity and related pathologies [13, 20, 21]. The shelf life of these highly perishable fruits can be prolonged by developing fermented food products such as fruit wines which are sources of energy, vitamins, minerals, and phytochemicals to consumers. Although most commercially produced fruit wines are developed from fermented grape and apple fruits or by blending grape wines, quality fruit wines could be produced by fermenting cactus pear with Lantana camara fruits $[22,23]$. This is due to important bioactive compounds such as flavonoids, saponin, terpenoids, tannin, and alkaloids which are present in both fruits' pulp which could be utilized for functional fruit wine development [17].

Perishable nature, seasonal cultivation, and dearth of processing technologies of the cactus pear and Lantana camara fruits hardly provoke postharvest losses. Hence, cactus pear fruit cultivars are demanding technologies that develop functional foods having long-term storage like wine and for better worldwide distribution. Fermentation plays a great role in enhancing fruit wine quality. Basically, a biochemical reaction occurs during fermentation, and sugars, total phenols, flavonoids, betalains, organic acids, and other bioactive compounds present in fruits affect the final total wine quality [12]. Many studies have reported on the possibilities of functional fermented foods such as lactic acid fermentation, kombucha beverage, and cactus pear wine development from the cactus pear fruit juice [14, 20, 24, 25]. "Colonche," a sweet alcoholic beverage reminiscent of the red wine obtained by natural fermentation of cactus pear fruit juice, is common in Mexico [26]. In Ethiopia, cactus pear fruits have not yet been incorporated into industrial wine production. Besides, basic qualities of cactus pear fruit wine could be improved by incorporating other fruits such as Lantana camara during the fermentation process. Only few studies have been conducted about basic quality profiles such as consumers' acceptance as well as health-related methanol, sulfite, and titratable acidity of the produced fermented food products. Investigating blended fruit wine's physicochemical properties could encourage wine production and increase consumers' perception. Therefore, fully interrelated physicochemical properties of both fruit juices with its final wine encourage the fruit wine consumers' acceptability. In the current study, prominent physicochemical properties of cactus pear and Lantana camara fruit juices and their blended fruit juice fermented wine product were characterized.

\section{Materials and Methods}

\subsection{Sample Development and Experimental Design Methods}

2.1.1. Chemicals. Baking yeast of Saccharomyces cerevisiae was purchased from a supermarket, Addis Ababa, Ethiopia, originated Angel Yeast (Hubei, Mainland, China). Chemicals used in the present study were procured from UNICHEM, India, and Loba-Chemie Laboratory Reagents and
Fine Chemicals Co. India, Mumbai, India. All chemicals and solvents used in this study were of analytical grade and used as supplied.

Mature cactus pear fruits (variety: Opuntia ficus-indica) were collected from farmers at Adigrat, Ethiopia, during the peak production time of June. Fruits were stored in an icebox at $6^{\circ} \mathrm{C}$ during half day transportation to Aksum University chemistry laboratory. Dark purple-colored Lantana camara (L. camara) fruits were collected using clean plastic bags from Aksum, Ethiopia, during June and stored in an icebox at $6^{\circ} \mathrm{C}$ until arrival at Aksum University chemistry laboratory. The Lantana camara plant and its fruit was previously identified and authenticated by a taxonomist and registered as a voucher specimen number of ET001 at the National Herbarium, College of Natural Sciences and Computation, Addis Ababa University [18].

\subsubsection{Cactus Pear and Lantana camara Fruit Juice Prepa-} ration and Preliminary Characterizations. Initially, orange type of matured cactus pear fruits was selected, sorted, and gently washed under running tap water and peeled manually to remove its outer coat. The edible part (pulp) was chopped using a domestic juicer machine (Electric Juicer, BL-727, Japan) to produce about $3.677 \mathrm{~g} / \mathrm{mL}$ of cactus pear juice. About $500 \mathrm{~g}$ of Lantana camara fruits were destemmed, sorted, and washed (twice) by immersing them in a plastic jar containing $3 \mathrm{~L}$ distilled water. The Lantana camara fruit juice was prepared using the domestic juicer machine (Electric Juicer, BL-727, Japan) after proper draining of the washed water. During Lantana camara fruit juice extraction, $1 \mathrm{~L}$ distilled water was added and $70 \%(\mathrm{w} / \mathrm{v})$ of juice was produced. Microbial contamination and fermentation was prevented by adding $70 \mathrm{mg} / \mathrm{L}$ sodium thiosulfate into each juice type. Both juices were preserved at $4^{\circ} \mathrm{C}$ until filtered using a sterilized cotton cloth mesh to remove the seed and fibers.

Qualities of the juices were preliminarily characterized based on $\mathrm{pH}$, total soluble solids ( $\left.{ }^{\circ} \mathrm{Brix}\right)$, sugar content, total phenol, and organic acids to assess the necessity of additional adjustments and nutrient addition. Measurements of these qualities are stated in Section 2.2.

2.1.3. Preparation of Yeast Strain. The yeast cell (biomass) was developed using $50 \mathrm{~mL}$ of sterilized YEPD media $(1 \%$ $(\mathrm{m} / \mathrm{v})$ yeast extract, $2 \%(\mathrm{~m} / \mathrm{v})$ peptone, $2 \%(\mathrm{~m} / \mathrm{v})$ glucose $)$ contained in a $150 \mathrm{~mL}$ sterilized conical flask. The $0.75 \mathrm{~g}$ dry baker yeast cell (Saccharomyces cerevisiae) (hydrated in $50 \mathrm{~mL}$ mild hot distilled water at $35^{\circ} \mathrm{C}$ ) was added into the YEPD media and diluted to $150 \mathrm{~mL}$ using sterilized distilled water. The mixture was incubated in a rotary shaker (VRN200, Gemmy Industrial Corp., Taiwan) with a speed of $120 \mathrm{rpm}$ at $28^{\circ} \mathrm{C}$ for 24 hours. Then, it was transferred into a $1000 \mathrm{~mL}$ Erlenmeyer flask which contained $500 \mathrm{~mL}$ of the sterilized cactus pear juice pulp that was previously adjusted with the sugar content of $200 \mathrm{~g} / \mathrm{L}, 70 \mathrm{mg} / \mathrm{L}$ sodium thiosulfate content, and a $\mathrm{pH}$ of 3.4 using a $\mathrm{pH}$ meter ( $\mathrm{PH}-016$, Kelilong Electron Co., China). The mixture was incubated at $28^{\circ} \mathrm{C}$ for 36 hours at a shaker speed of $150 \mathrm{rpm}$ to use it directly for wine fermentation [25]. 
2.1.4. Fermentations and Stabilization Process. The final extracted cactus pear juice was adjusted with appropriate sugar content $(200 \mathrm{~g} / \mathrm{L}$ equivalent to dextrose), $\mathrm{pH}$ of 3.4 (using $0.5 \mathrm{~g} / \mathrm{L}$ tartaric acid solution), and $\mathrm{SO}_{2}(70 \mathrm{mg} / \mathrm{L})$ in $5 \mathrm{~L}$ plastic jar. The remaining factors like temperature, inoculum concentration $\left(1.7 \times 10^{6} \mathrm{CFU} / \mathrm{mL}\right)$, and volume of Lantana camara fruit juice were adjusted according to previously optimized fermentation design points. These are fermentation temperature $\left(24.8^{\circ} \mathrm{C}\right)$, inoculum concentration $(10.16 \%(\mathrm{v} / \mathrm{v}))$, and Lantana camara fruit juice concentration $(10.66 \%(\mathrm{v} / \mathrm{v}))$. The fermentation process was developed in spherical $500 \mathrm{~mL}$ glass flasks that have equal volume and shape containing $3 / 4^{\text {th }}$ of the adjusted cactus pear fruit juice. The fermentation process was carried out for six days [25]. Free run of the fermented products was filtered from each sample using a sterilized cotton cheesecloth. Each sample was packaged in $330 \mathrm{~mL}$ sterilized brown glass bottles. Finally, four replicates of each wine sample were pasteurized at a temperature of $65^{\circ} \mathrm{C}$ for 20 minutes and preserved by adding $70 \mathrm{mg} / \mathrm{L} \mathrm{SO}_{2}$ for twenty days at room temperature $\left(24^{\circ} \mathrm{C}\right)$.

\subsection{Physicochemical Characterization Methods of the Fruit Juice and Wine Quality}

2.2.1. $\mathrm{pH}$ and ${ }^{\circ}$ Brix. The $\mathrm{pH}$ and ${ }^{\circ}$ Brix of each fruit juices and the produced wine were determined with a digital $\mathrm{pH}$ meter (PH-016, Kelilong Electron Co., China) and digital refractometer (DR6200/2, A. KRUSS Optronic, Germany). During the $\mathrm{pH}$ and ${ }^{\circ} \mathrm{Brix}$ measurement, $100 \mathrm{~mL}$ of fruit juices and wine samples was filtered using a cotton cloth mesh.

2.2.2. Color of the Wine. The color of the produced wine was analyzed using a UV-Vis spectrophotometer (UV-5100 Spectrophotometer, Metash Instruments Co., Ltd., Shanghai, China) and $1 \mathrm{~cm}$ cell path length at $A_{420 \mathrm{~nm}}, A_{520 \mathrm{~nm}}$, and $A_{620 \mathrm{~nm}}$ by applying the procedure described by Yildirim [10]. Color density $\left(A_{420}+A_{520}\right)$, shade or tint $\left(A_{420} / A_{520}\right)$, and color intensity (CI) $\left(A_{420 \mathrm{~nm}}+A_{520 \mathrm{~nm}}+A_{620 \mathrm{~nm}}\right)$ were used to describe the produced wine color using distilled water as a blank. Accordingly, proportions of red (\%R), yellow (\%Y), and blue $(\% \mathrm{~B})$ were determined as $A_{520 \mathrm{~nm}} \times 100 / \mathrm{IC}$, $A_{420 \mathrm{~nm}} \times 100 / \mathrm{IC}$, and $A_{620 \mathrm{~nm}} \times 100 / \mathrm{IC}$, respectively.

2.2.3. Estimation of Sugar. The sugar content of both the juices was measured using the phenol- $\mathrm{H}_{2} \mathrm{SO}_{4}$ method as described by Nielsen [27]. First, $1 \mathrm{~mL}$ of each juice samples was diluted into $150 \mathrm{~mL}$ distilled water and mixed properly. Next, into test tubes containing $2 \mathrm{~mL}$ standard sugar solution (dextrose glucose) of 5, 10, 25, 50, and $75 \mathrm{mgL}^{-1}$ as well as $2 \mathrm{~mL}$ of each diluted fruit juice and wine samples, $1 \mathrm{~mL}$ of $5 \%$ phenol solution in water and $5 \mathrm{~mL}$ of concentrated sulphuric acid were added with sufficient mixing. The residual sugar content of the wine sample was determined by diluting $1 \mathrm{~mL}$ of the cotton cloth mesh filtered wine product into $50 \mathrm{~mL}$ using distilled water. Finally, the sugar content of juices and wine was calculated from the calibration equation $Y=0.0127 x+0.0131$ at $R^{2}=0.996$, where $Y$ and $x$ stand for absorbance reading and sugar concentration expressed in $\mathrm{g} /$ $\mathrm{L}$ equivalent to dextrose glucose, respectively.

\subsubsection{Total Acidity (TA). Cactus pear and Lantana camara} fruit juice was filtered using a cotton cloth mesh and 1:5 (diluted with distilled water) of the fruit juice were titrated by $0.1 \mathrm{~N}$ of $\mathrm{NaOH}$ to the phenolphthalein color endpoint detection. A digital burette (Titrette, Brand Gmbh + Co KG, Wertheim, Germany) was used to determine the titration volume. Finally, the total acidity was calculated (as tartaric acid is the predominant acid in both fruits) using equation (1).

Total acidity (TA) of the wine sample was measured according to the procedure described by OIV [28] by taking $50 \mathrm{~mL}$ of filtered wine sample solution sample into a $250 \mathrm{~mL}$ conical flask. To remove carbon dioxide, the sample containing flask was blown using a vacuum pump with continuous shaking for one to two minutes. A digital burette (Titrette, Brand Gmbh + Co KG, Wertheim, Germany) was used to determine the titration volume. From each sample, $10 \mathrm{~mL}$ of the $1: 5$ diluted solution was titrated with standardized $0.1 \mathrm{~N} \mathrm{NaOH}$ to the bromothymol blue endpoint (blue-green color). The bromothymol blue solution was prepared by mixing $1 \mathrm{~mL}$ of bromothymol blue solution and $25 \mathrm{~mL}$ of boiled distilled water. The volume of $\mathrm{NaOH}$ was converted to gram of citric acid (predominant acid in the wine sample) per $L$ of juice and wine sample; at last, TA was estimated using the following equation [29]:

$$
T A\left(\% \frac{w}{v} \text { predominant acid }\right)=\frac{N \times V_{1} \times \text { Eq.wt. }}{V_{2} \times 10},
$$

where $T A=$ total acidity, $N=$ normality of the titrant (mEq/ $\mathrm{ml}), V_{1}=$ volume of the titrant $(\mathrm{mL}), V_{2}=$ volume of the sample (mL), and Eq.wt. = equivalent weight of the predominant acid.

2.2.5. Estimation of Ethanol. In each wine sample, the ethanol concentration (\%, v/v) was determined using acidified dichromate solution according to the procedure described by Babu et al. [30]. Each wine sample was distilled according to the method used by Zenebe et al. [25]. Absorbance reading of wine samples cooled to room temperature was measured at $600 \mathrm{~nm}$ using a spectrophotometer (UV-5100 Spectrophotometer, Metash Instruments Co., Ltd., Shanghai, China). The standard ethanol solutions were prepared as $2,6,8,12$, and $14 \%(\mathrm{v} / \mathrm{v})$ in distilled water. Finally, ethanol concentrations were determined with the calibration equation of $Y=0.097 x-0.036$ with $R^{2}=0.996$, where $Y$ and $x$ represent ethanol absorbance reading and ethanol concentration (\% v/v), respectively.

2.2.6. Total Phenol. Total phenol contents of each wine sample were determined according to the procedure described by Arrizon et al. [31] with some modifications. In brief, $1 \mathrm{~mL}$ of each wine samples was diluted into $150 \mathrm{~mL}$ using distilled water. The calibration equation was developed 
using standard gallic acid solutions of 10, 25, 50, 100, 150, and $200 \mathrm{mg} / \mathrm{L}$ in distilled water. Absorbance of samples, standards, and the blank solution was measured at $765 \mathrm{~nm}$ using a spectrophotometer (UV-5100 Spectrophotometer, Metash Instruments Co., Ltd., Shanghai, China). The concentration of total phenol in every wine sample was determined from the calibration equation $Y=0.0117 x+0.0188$ with $R^{2}=0.9995$, where $Y$ and $x$ indicate total phenol absorbance reading and total phenol concentration $(\mathrm{mg} / \mathrm{L}$ EGA), respectively.

2.2.7. Organic Acids. The high-performance liquid chromatography (HPLC) technique equipped with a diode array detector (DAD) monitored at $210 \mathrm{~nm}$ with a pump system (1260, Agilent Technologies, Palo Alto, CA, USA) was used. Moreover, the UV-Vis spectra (scanning from $0 \mathrm{~nm}$ to $1600 \mathrm{~nm}$ ) were recorded for all peaks. The organic acid content of each juice and wine sample was analyzed onto a $\mathrm{C}_{18}$ 70RBAX-ODS column $(250 \times 4.6 \mathrm{~mm}$ and $5 \mu \mathrm{m}$ particle size) (Agilent Technologies, USA) kept at $40^{\circ} \mathrm{C}$. Each juice sample was freshly squeezed and filtered using a cotton cloth. Then, the juice and wine samples were filtered by using a $0.45 \mu \mathrm{m}$ Whatman nylon membrane filter (GE Healthcare, USA). Filtered $0.168 \mathrm{~g} / \mathrm{mL}$ cactus pear and $0.1 \mathrm{~g} / \mathrm{mL}$ Lantana camara fruit juices were used for measurement. Each sample was measured in triplicate. Samples were measured in the analytical conditions with flow rate $=10 \mu \mathrm{L} / \mathrm{min}$ and $0.045 \mathrm{~N}$ $\mathrm{H}_{2} \mathrm{SO}_{4}$ eluent with $6 \%$ acetonitrile (v/v) [24, 32]. Retention time comparison to external standards $(0.002 \mathrm{~g} / \mathrm{mL})$ of citric, L-tartaric, L-ascorbic, and oxalic acids, followed by concentration estimation using the relative peak area covered in the chromatogram, was used to compare and calculate organic acid concentration. The organic acid concentration was calculated using the following equation:

$$
\text { Organic acid concentration }\left(\frac{\mathrm{mg}}{\mathrm{mL}}\right)=\frac{\text { peak area of sample }}{\text { peak area of standard }} \times \text { concentration of standard. }
$$

2.2.8. Methanol Analysis. The methanol content (mg/L) in the wine sample was analyzed according to the procedure developed by Zhan et al. [33]. The chromogenic reagent (SNP) was prepared by adding $100 \mathrm{~mL}$ of $10 \%(\mathrm{~m} / \mathrm{v})$ sodium nitroprusside, $10 \%(\mathrm{~m} / \mathrm{v})$ potassium ferricyanide, and $5 \%$ $(\mathrm{m} / \mathrm{v}) \mathrm{NaOH}$ into a plastic container, respectively, and the solution was diluted to $600 \mathrm{~mL}$ after proper mixing. The mixture (SNP) was preserved without light at $4^{\circ} \mathrm{C}$ before use. Methanol was used as a standard solution $(0.25,1,2,3,4,5$, and $6 \mathrm{mg} / \mathrm{mL}$ ) to prepare the calibration curve. The distillation was carried out using the method in OIV-MA-AS31201A [34]. From $200 \mathrm{~mL}$ of the wine sample, $198.5 \mathrm{~mL}$ distillate was collected using fractional distillation. Then, the distilled wine sample was diluted into $200 \mathrm{~mL}$ using distilled water. In the test tubes containing $1 \mathrm{~mL}$ of standard and sample solution, $6 \mathrm{~mL}$ of chromogenic reagent (SNP) was added. The solution was reacted for $15 \mathrm{~min}$ at room temperature $\left(23^{\circ} \mathrm{C}\right)$, and absorbance of the solution was measured at $481 \mathrm{~nm}$ against a blank $(1.8 \mathrm{mg} / \mathrm{mL}$ ethanol) with same reagent concentrations except for methanol. Methanol concentration was calculated from the calibration equation: absorbance reading $=0.0528 x-0.0002$ at $R^{2}=0.9941$, where $x$ represents methanol concentration in $\mathrm{mg} / \mathrm{mL}$.

2.2.9. Free and Total Sulfur Dioxide $\left(\mathrm{SO}_{2}\right)$. The free and total sulfur dioxide was measured according to the method of OIV (OIV-MA-AS323-04B) [35]. Free sulfur dioxide was measured by taking $50 \mathrm{~mL}$ of wine sample into a $500 \mathrm{~mL}$ conical flask containing $5 \mathrm{~mL}$ starch solution $(5 \mathrm{~g} / \mathrm{L}), 30 \mathrm{mg}$ EDTA, and $3 \mathrm{~mL}$ of $10 \% \mathrm{H}_{2} \mathrm{SO}_{4}$. This solution was titrated with $0.025 \mathrm{M}$ iodine solution directly until blue color continued to exist for 10 to 15 seconds. The volume of iodine consumed was recorded and coded as $n$.
The total sulfur dioxide was determined by adding $8 \mathrm{~mL}$ of $4 \mathrm{M}$ sodium hydroxide solution to the solution in which free $\mathrm{SO}_{2}$ has been determined; it was settled for 5 minutes after shaking once, and then $10 \mathrm{~mL}$ of $10 \% \mathrm{H}_{2} \mathrm{SO}_{4}$ was added with vigorous stirring. Finally, it was titrated with $0.025 \mathrm{M}$ iodine solution, and the volume consumed was noted as $n^{\prime} .20 \mathrm{~mL}$ of sodium hydroxide solution was added again, allowed to stand for 5 minutes after shaking and diluting by $200 \mathrm{~mL}$ of ice-cold water. While stirring vigorously, $30 \mathrm{~mL}$ sulphuric acid was added at the same time and lastly titrated using $0.025 \mathrm{M}$ iodine solution. The final volume was noted as $n "$. Finally, free and total sulfur dioxide was calculated as $32 \times n$ and $32 \times\left(n+n^{\prime}+n^{\prime \prime}\right)$ in milligrams per liter, respectively.

2.2.10. Sensory Evaluation. A semitrained panel of judges (their age group is between 24 and 45) who participated in previous cactus pear fruit wine evaluation, 3 females and 3 males, analyzed the sensory characteristics of the wine samples [36]. Randomly distributed $30 \mathrm{~mL}$ wine samples filled into $150 \mathrm{~mL}$ tulip-shaped wine glasses (covered with watch-glass) were evaluated by the panelist. Each panelist evaluated every wine sample three times for color, taste, flavor, and overall acceptability on the nine-point hedonic scale (From 1 =dislike extremely to $9=$ like extremely). Evaluation condition was maintained using the procedure described by Zenebe et al. [25].

2.3. Methods of Data Analysis. The results from the experimental work were analyzed using a statistical framework based on the analysis of variance (ANOVA) procedures during analyzing data of wine characterizations. Microsoft Excel 2013 version 15.0.4981.1001 (Microsoft Corporation, Redmond, WA, USA) was used to develop calibration equations and investigate the adequacy of experimental data. 


\section{Results and Discussion}

3.1. General Physicochemical Composition of Cactus Pear and Lantana camara Fruit Juices and the Wine Sample. Preliminary physicochemical properties of the current wine fermentation substrate (cactus pear) as well as the additive (Lantana camara) fruit juices were characterized based on $\mathrm{pH}$, total soluble solids ( $\left.{ }^{\circ} \mathrm{Brix}\right)$, sugar content, total phenol, and organic acids for further adjustment. Table 1 presents the general physicochemical properties of both cactus pear and Lantana camara fruits as well as their wine product. Moreover, color, methanol, ethanol, and sulfite content of the produced wine were determined to show its quality profile (Table 2). Consumers' acceptance based on sensory value was also determined as shown in Table 2.

3.1.1. $\mathrm{pH}$, ${ }^{\circ}$ Brix, and Total Acidity of Cactus Pear and Lantana camara Fruit Juices and Wine Sample. $\mathrm{pH},{ }^{\circ}$ Brix, and total acidity of both juices as well as the final wine are shown in Table 1. It can be seen from Table 1 that both fruits have preliminary pH value of 5.5 (cactus pear) and 5.9 (Lantana camara) which indicates further $\mathrm{pH}$ adjustment was required before using it for wine fermentation substrate. The measured $\mathrm{pH}$ of cactus pear fruit juice and the wine is similar to the result reported by other researchers $[13,14]$. As a result, the $\mathrm{pH}$ of the cactus pear fruit juice fermentation substrate was adjusted to a $\mathrm{pH}$ of 3.4 using $0.5 \mathrm{~g} / \mathrm{L}$ tartaric acid solution. The measured wine sample $\mathrm{pH}$ is similar to $\mathrm{pH}$ measured in kiwifruit wine $(\mathrm{pH}=3.55)$, herbal purple sweet potato wine $(\mathrm{pH}=3.34)$ but lower than the tropical bael (Aegle marmelos L.) fruit wine ( $\mathrm{pH}=4.1)$ [37-39]. After the fermentation process, $\mathrm{pH}$ of the produced wine has shown similar $\mathrm{pH}$ value with the adjusted fermentation substrate which is consistent with the study reported by Kelebek and Selli [11]. Although physiological activities of yeasts, lactic acid bacteria, and produced organic acids are responsible for $\mathrm{pH}$ decrease of the fruit wine during alcoholic fermentation, insignificant $\mathrm{pH}$ difference between the adjusted substrate and the final wine was observed in the current study. This is expected to be caused by low $\mathrm{pH}$ in the early fermentation stage of the fruit wine $[6,14]$. The $\mathrm{pH}$ of the final wine was not affected by the addition of Lantana camara fruit juice.

The Brix degree (percentage of dissolved solids) of cactus pear and Lantana camara fruit juices was measured $4.3^{\circ} \mathrm{Brix}$ and $6.4^{\circ}$ Brix, respectively. But, the Brix degree of produced wine has decreased due to some dissolved solids such as sugars solubilized as a biochemical reaction to produce alcohol, carbon dioxide, and organic acids. In the current study, the Brix degree was measured slightly greater than the wines produced from sapota (Achras sapota Linn.) $\left(2.38^{\circ}\right.$ Brix) and bael (Aegle marmelos L.) $\left(2.91^{\circ}\right.$ Brix) fruits and potato $\left(4.0^{\circ} \mathrm{Brix}\right)$ [38-40]. The reduction of soluble solids after fermentation process was similarly reported by other studies. But, lower Brix degree value of the cactus pear fruit juice was observed in the current study as compared to other reported studies [13, 14, 41].

The HPLC chromatograms shown in Figures 1 and 2 indicate the presence of the following organic acids in both fruit juices: citric acid, tartaric acid, and ascorbic acid. From the HPLC analysis, L-tartaric acid was dominantly identified in both cactus pear and Lantana camara fruits. As a result, tartaric acid was used as a predominant acid during the total acidity calculation of both fruit juices. Total acidity of both juices and the wine produced is shown in Table 1. The measured total acidity of cactus pear fruit juice has lower value than the measured result reported by Ayed and Hamdi [14] and Panda et al. [41]. But, it is consistent with study reported by Chavez-Santoscoy et al. [13]. The difference can be due to the difference in origin of the fruit as well as conditions of harvesting time (where the current fruit was harvested during summer season). Furthermore, juices of both fruits have low total acidity content as compared to other citrus fruits (orange and lemon) in which citrus fruits are supposed to contain better titratable acidity [32, 42, 43]. Moreover, as it can be seen in Figure 3, the wine sample has predominant organic acid of citric acid, and the total acidity of the wine was calculated based on citric acid. The current wine has lower titratable acidy than that reported on kiwi as well as orange fruit wines (about $6.3 \mathrm{~g} / \mathrm{L}$ for orange fruit wine and $13.6 \mathrm{~g} / \mathrm{L}$ for kiwifruit wine equivalent to citric acid) $[32,37]$. Tartaric acid was the second predominant acid identified using the HPLC. Total acidity of the final wine was increased to about $0.33 \%(\mathrm{w} / \mathrm{v})$ of citric acid. Greater overall amounts of organic acids present in fruit musts can be altered in the final wine due to the difference in the degree of dissociation of organic acids $[6,44]$. The final wine was not affected by the added Lantana camara fruit juice. Generally, total acidity of the final wine was greater in both fruit juices due to the course of fermentation which is consistent with other reported studies $[14,25,41]$.

\subsubsection{Total Phenol and Organic Acid Contents of the Cactus} Pear and Lantana camara Fruit Juices and the Wine Sample. Table 1 shows the total phenolic composition of both fruits and the produced wine. The Lantana camara fruit has higher total phenol content than the cactus pear fruit. Both cactus pear and Lantana camara fruits are naturally rich in flavonoids, betalains, and phenolic acids such as gallic, chlorogenic, and caffeic acids. Specifically, betaxanthin type of betalain is predominantly found in yellow-orange color cactus pear fruits $[14,45]$. Initially, total phenol content of the cactus pear fruit must was measured as $326 \mathrm{mg} / \mathrm{L}$ equivalent to gallic acid. The measured total phenol content in the current study is lower than that reported by Ayed and Hamdi [14]. During the fermentation process, $10 \% \mathrm{v} / \mathrm{v}$ of the Lantana camara fruit juice (with about $607 \mathrm{mg}$ gallic acid/L) was added to the fermentation substrate. Hence, the total phenol content of the final wine was enhanced which is similar to other reported studies $[6,14]$. The large total phenol content is related with total polyphenolic contents of the added Lantana camara fruit juice. Total phenolic content of fruit wines can be affected by the color of fermenting substrate and different winemaking procedures such as prolonged extraction time [10]. So, in the current study, total phenol of the final wine was supposed to be enhanced since Lantana camara berries used as an additive had a strong 
TABLE 1: General composition of cactus pear and Lantana camara fruit juices and wine sample.

\begin{tabular}{|c|c|c|c|}
\hline Parameter & $\begin{array}{l}\text { Cactus pear fruit juice } \\
\text { Mean, SD }\end{array}$ & $\begin{array}{c}\text { Lantana camara fruit juice } \\
\text { Mean, SD }\end{array}$ & $\begin{array}{l}\text { Wine } \\
\text { Mean, SD }\end{array}$ \\
\hline $\mathrm{pH}$ & $5.9 \pm 0.17$ & $5.5 \pm 0.21$ & $3.47 \pm 0.04$ \\
\hline${ }^{\circ}$ Brix & $4.3 \pm 0.01$ & $6.4 \pm 0.00$ & $4.1 \pm 0.03$ \\
\hline Sugar content (g/L dextrose) & $93.8 \pm 14.5$ & $56.0 \pm 0.45$ & $4.6 \pm 0.02$ \\
\hline $\begin{array}{l}\text { Total acidity (\% w } / v \text { tartaric acid for both juices and } \\
\text { citric acid for the wine sample) }\end{array}$ & $0.10 \pm 0.01$ & $0.13 \pm 0.01$ & $0.33 \pm 0.01$ \\
\hline $\begin{array}{l}\text { Total phenol (mg/L gallic acid) } \\
\text { Organic acids }\end{array}$ & $326.4 \pm 27.8$ & $607.1 \pm 40.82$ & $696.1 \pm 22.1$ \\
\hline Citric acid $(\mathrm{mg} / \mathrm{ml})$ & $0.16 \pm 0.04$ & $0.054 \pm 0.02$ & $4.35 \pm 0.4$ \\
\hline L-tartaric acid $(\mathrm{mg} / \mathrm{ml})$ & $0.92 \pm 0.01$ & $0.31 \pm 0.07$ & $1.1 \pm 0.67$ \\
\hline L-ascorbic acid (mg/ml) & $0.02 \pm 0.01$ & $0.009 \pm 0.03$ & $0.12 \pm 0.00$ \\
\hline Oxalic acid $(\mathrm{mg} / \mathrm{ml})$ & ND & ND & ND \\
\hline Total organic acid content $(\mathrm{mg} / \mathrm{ml})$ & $1.1 \pm 0.07$ & $0.37 \pm 0.08$ & $5.57 \pm 0.14$ \\
\hline
\end{tabular}

ND: not determined.

TABLE 2: Color, alcohol, sulfite content, and sensory value of the wine sample.

\begin{tabular}{lc}
\hline Wine composition & Mean $\pm \mathrm{SD}$ \\
\hline Color & \\
Color density $\left(A_{420 \mathrm{~nm}}+A_{520 \mathrm{~nm}}\right)$ & $0.92 \pm 0.03$ \\
Shade $\left(A_{420 \mathrm{~nm}} / A_{520 \mathrm{~nm}}\right)$ & $1.40 \pm 0.14$ \\
Color intensity $(\mathrm{CI})\left(A_{420 \mathrm{~nm}}+A_{520 \mathrm{~nm}}+A_{620 \mathrm{~nm}}\right)$ & $0.94 \pm 0.03$ \\
$\% Y$ & $48.07 \pm 2.66$ \\
$\% R$ & $34.53 \pm 1.96$ \\
$\% B$ & $1.77 \pm 0.09$ \\
Overall sensory acceptability & $8.65 \pm 0.92$ \\
Alcohol & \\
Ethanol $(\% \mathrm{v} / \mathrm{v})$ & $8.6 \pm 0.68$ \\
Methanol $(\mathrm{mg} / \mathrm{L})$ & $124.4 \pm 9.5$ \\
Sulfite content & \\
Free $\mathrm{SO}_{2}(\mathrm{mg} / \mathrm{L})$ & $60.6 \pm 1.8$ \\
Total $\mathrm{SO}_{2}(\mathrm{mg} / \mathrm{L})$ & $129.94 \pm 4.04$ \\
\hline
\end{tabular}

$Y, R$, and $B$ refer to proportions of red, yellow, and blue in the wine product.

purple color (higher phenolic contents) as bilberries and blackberry fruits. Polyphenols are responsible for free radical scavengers (show antioxidant activities) by quenching hydroxyl radicals or superoxide anion radicals [39].

The occurrence of acid hydrolysis in cactus pear fruit must and bioconversion of condensed phenolic compounds present in the Lantana camara fruit during fermentation process could enhance the total phenol content of the final wine. Similarly, ethanolic extracts of Lantana camara contains mainly bicyclogermacrene, caryophyllene, valencene, and germacrene which could increase total phenolic content of the cactus pear fruit wine [14, 45]. Besides, nonphenolic compounds in the fermenting substrate can be converted into phenolic compounds by yeast due to hydrolytic enzymes such as esterase which could release soluble conjugated or insoluble bound phenolic acids from the cell walls of the raw material [46]. The improvement of polyphenol content and bioactive compounds in the final wine is in agreement with other studies conducted on fermenting apple-herb wine, sweet potato herbal wine, ball-milled achenes with strawberry wine, and wine from watermelon juice and ginger extract $[5-7,38]$.
High-performance liquid chromatography (HPLC) is a fast and accurate method to measure organic acids such as tartaric, malic, ascorbic, citric, etc., in fruit juices and wine samples [32, 47]. Both fruits are not citrus fruits, and the measured organic acid compositions are low compared to measured values in mandarin, orange, pineapple, etc. $[11,32]$. Composition of organic acids in the fruit wine has resulted from the wine substrates used and organic acids produced by yeasts during the fermentation process. These organic acids are responsible for the sour taste of fruit wines [6]. HPLC chromatograms of organic acids in cactus pear and Lantana camara fruits and the final wine are shown in Figures 1-3, respectively. Three types of organic acid (citric, L-tartaric, and L-ascorbic acids) and other unknown organic acids were separated and identified in both fruit juices and the final wine. According to the study reported by Navarrete-Bolaños [24], oxalic acid was detected in the HPLCmeasured cactus pear young wine. But, in the current study, oxalic acid was not detected in both fruit juices as well as in the final wine (Figures 1-3) which could be due to the difference in the fermentation method and origin of the cactus pear fruit difference used. The major organic acid found in both fruits was L-tartaric acid (cactus pear $=0.92 \mathrm{mg} / \mathrm{mL}$ and Lantana camara $=0.31 \mathrm{mg} / \mathrm{mL}$ ), and the next abundant acid was citric acid (cactus pear $=0.16 \mathrm{mg} / \mathrm{mL}$ and Lantana camara $=0.054 \mathrm{mg} / \mathrm{mL}$ ). The Lantana camara fruit juice contained lower total organic acid $(0.37 \mathrm{mg} / \mathrm{mL})$ than the cactus pear fruit juice $(1.1 \mathrm{mg} /$ $\mathrm{mL})$. Hence, the Lantana camara fruit was supposed to have less effect on the organic acid content of the final wine. Although organic acids in the fruit substrate are supposed to be lost during fermentation due to their solubility property, enrichment of organic acid of the final wine in the current study was observed (by about $4.4 \mathrm{mg} / \mathrm{mL}$ total organic acid was increased) [5,32]. Citric acid is the most abundant $(4.35 \mathrm{mg} / \mathrm{mL})$ organic acid in the final wine. The baking yeast extract of Saccharomyces cerevisiae has changed the total organic acid profile as well as wine sensory properties in the current study [48]. The presence of tartaric acid in the produced cactus wine is consistent with the study [24]. Generally, the main reason for increased total organic acid in 


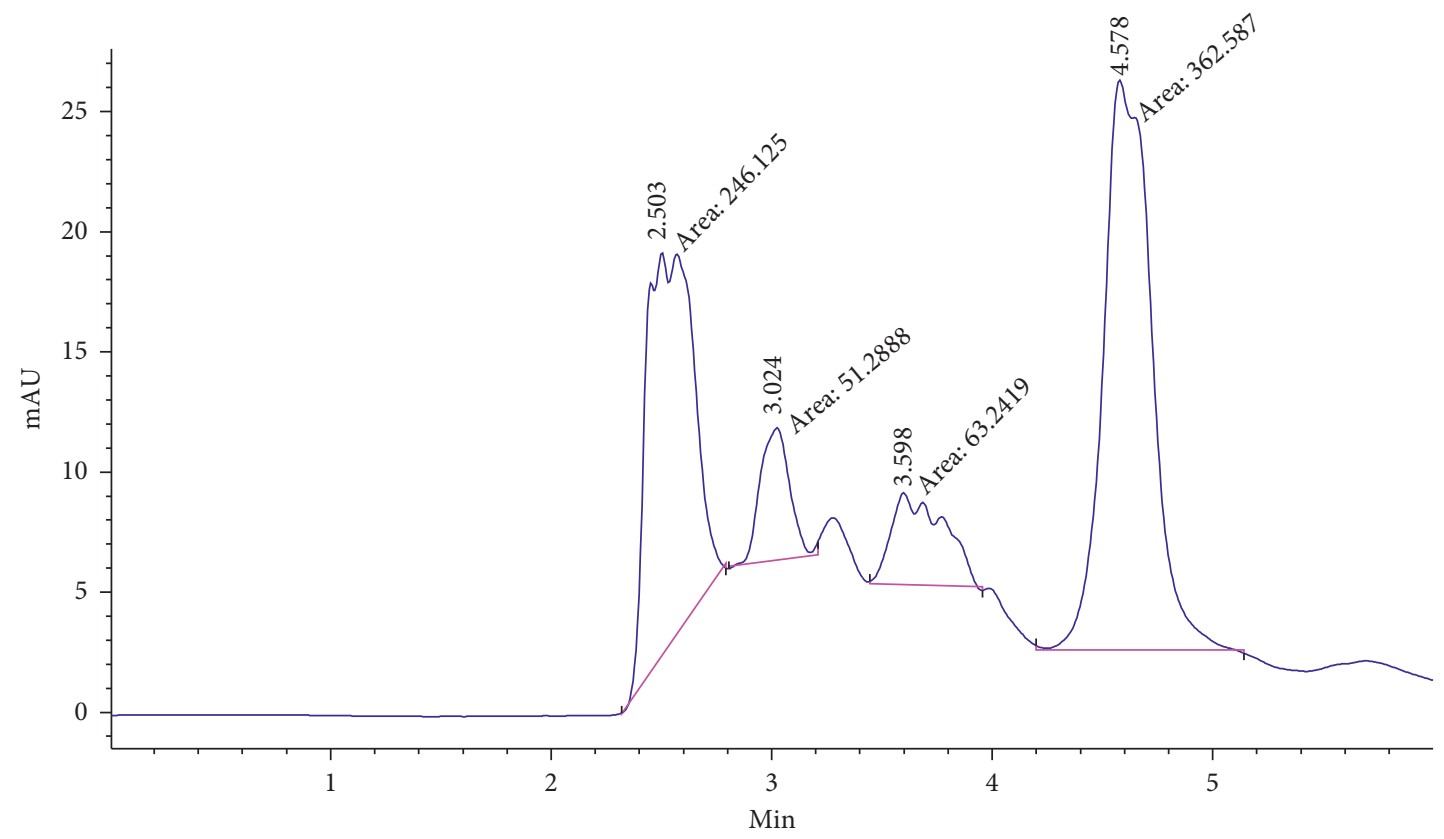

FIGURE 1: HPLC chromatogram for organic acids in Lantana camara fruit juice at $210 \mathrm{~nm}$ (peak area: 1; citric acid =63.24; 2 . L-tartaric acid $=246.12 ; 3$. L-ascorbic acid $=51.304$; oxalic acid $=$ not detected and others are unknown).

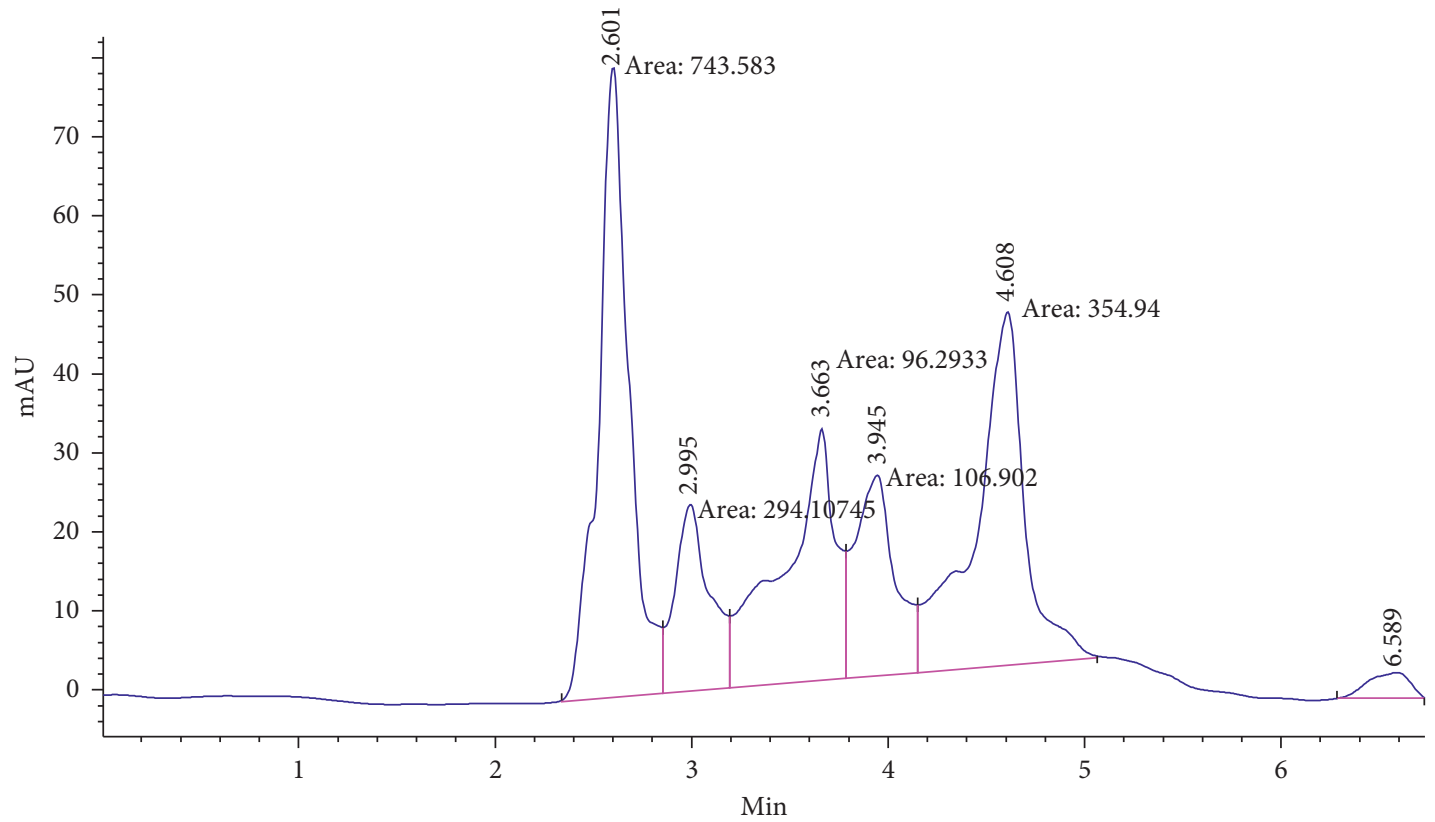

Figure 2: HPLC chromatogram for organic acids in cactus pear fruit juice at $210 \mathrm{~nm}$ (peak area: 1; citric acid=96.30; 2 . L-tartaric acid $=743.58 ; 3$. L-ascorbic acid $=106.744$; oxalic acid $=$ not detected and others are unknown)

the final wine is due to tartaric acid which was used for $\mathrm{pH}$ adjustment and conversion of the fruit's sugar into organic acids during the fermentation process [48].

3.1.3. Color, Alcohol, and Sulfite Content of the Wine. Color properties of the produced wine are shown in Table 2. Brightness or shade (hue) of the cactus pear fruit fermented with Lantana camara fruit was evaluated by the ratio of absorbance readings at $420 \mathrm{~nm}$ to the $520 \mathrm{~nm}\left(A_{420 \mathrm{~nm}} /\right.$
$\left.A_{520 \mathrm{~nm}}\right)$. This gives an estimation of the color change toward the orange tones observed in wines during aging [49]. Moreover, color intensity (CI) was calculated from the total absorbance readings $\left(A_{420 \mathrm{~nm}}+A_{520 \mathrm{~nm}}+A_{620 \mathrm{~nm}}\right)$ for the chromaticity which corresponds with estimation of the total color of the sample. As shown in Table 2, brightness or shade of the wine is greater than the color density as well as the color intensity (CI). The measured value of brightness or shade is lower than that reported on apple wine fermented with a medicinal herb which could be due to the difference of 


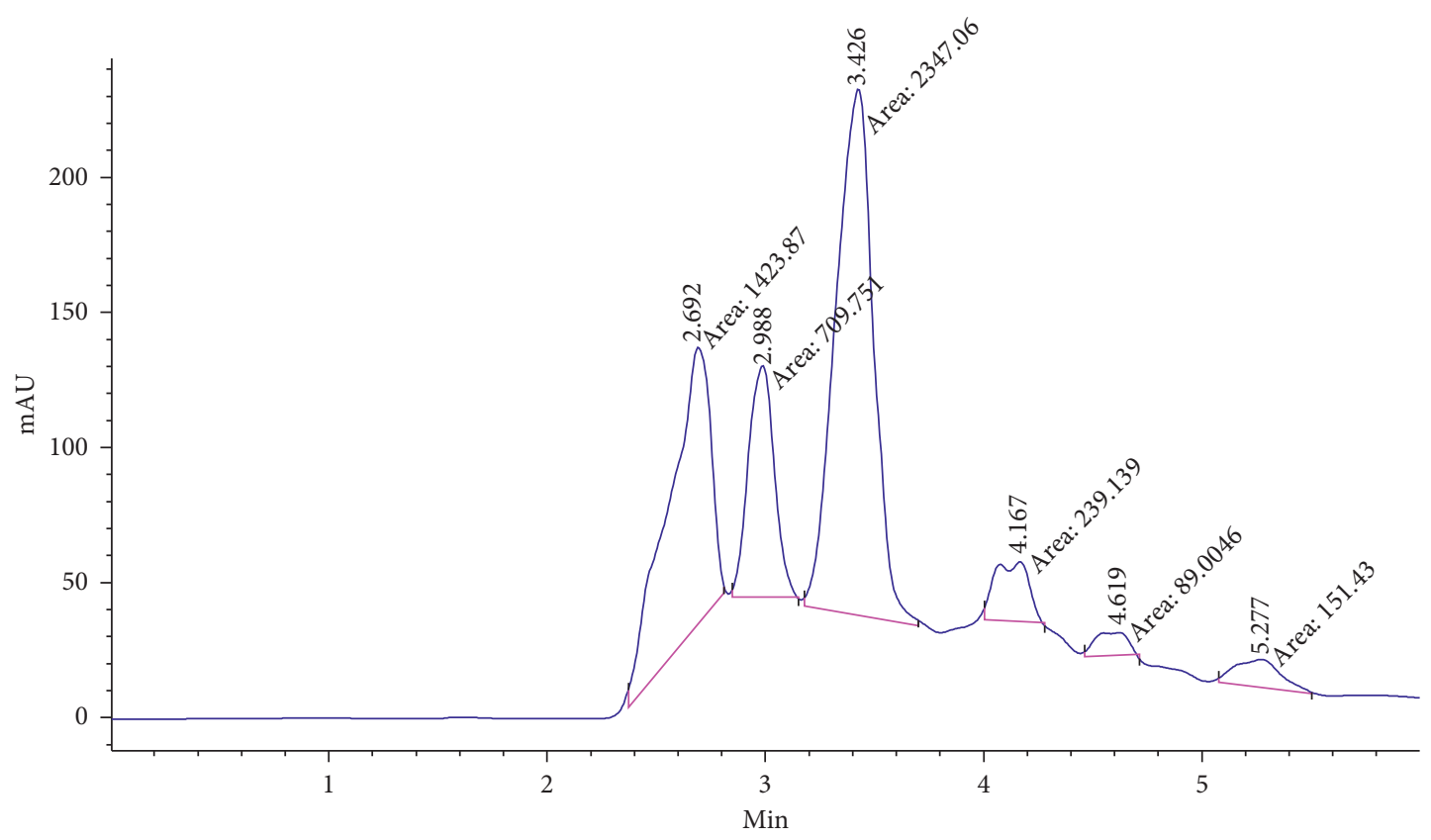

FiguRE 3: HPLC chromatogram for organic acids of the final wine at $210 \mathrm{~nm}$ (peak area: 1 ; citric acid = 2347.06; 2. L-tartaric acid = 1423.87; 3. $\mathrm{L}$-ascorbic acid $=709.754$; oxalic acid $=$ not detected and others are unknown)

material color between cactus with Lantana camara and apple with medicinal herb [6]. The biochemical reactions of anthocyanins with other phenolic compounds occurred during fruit wine fermentation process as well as during the wine aging are responsible for the color improvement of the produced wine.

$\% Y, \% R$, and $\% B$ shown in Table 2 correspond to the percentages of yellow, red, and blue values in the wine sample, respectively. Wine absorbance at $420 \mathrm{~nm}$ and $520 \mathrm{~nm}$ resembles the yellow and red colorations to show wine color (color intensity or color density) [49]. Due to orange to the yellow color of the cactus pear fruit juice and the added purple color of Lantana camara fruit juice during the fermentation process, the final wine predominantly has shown yellowish color (Table 2) which is consistent with the report studied on citrus fruit wines [50].

The alcoholic content of fruit wine is in accordance with the fermentation behavior of each type of musts of the fruits. Fruit juices with low sugar content tend to produce wine with lower ethanol. In the current study, since the sugar content of both fruits (Table 1) is low, amelioration with table sugar was carried out during inoculum as well as fermentation fruit substrate preparation. Ethanol in the produced wine contributes to the total quality characteristic such as flavor. As can be seen in Table 2, the ethanol content of the produced wine is equivalent to moderate grape wines. Similarly, the measured ethanol value of the current wine is comparable with the wine produced from mango (Mangifera indica L.), herbal purple sweet potato, and previously produced cactus pear fruit wine $[25,38,42]$. But, slightly larger amount of ethanol content was recorded compared to other reports on different wine substrates such as apple tea (7.9 to $8.19 \% \mathrm{v} / \mathrm{v})$, apple cider vinegar $(6.05 \% \mathrm{v} / \mathrm{v})$, sapota (Achras sapota Linn.) $(8.23 \% \mathrm{v} / \mathrm{v})$, and tropical bael (Aegle marmelos
L.) $(7.87 \% \mathrm{v} / \mathrm{v})[36,39,40,51]$. The difference could be due to the nature of the substrate (fruit juice type) and method of fermentation process used.

In the present study, the cactus pear fruit substrate was prepared without adding pectinolytic enzymes and thermal treatments by considering its negative impacts on sensory properties and methanol in the final wine. Hence, it was supposed that the final wine could contain less methanol content. As it can be seen in Table 2, the produced wine is lower than the methanol content reported on mango (Mangifera indica L.) wine (from 300 to $500 \mathrm{mg} / \mathrm{L}$ ) and kiwifruit wines $(663 \mathrm{mg} / \mathrm{L})$ but higher when compared to the grape wine (less than $100 \mathrm{mg} / \mathrm{L}$ ) [37, 42]. Moreover, in the present study, the fruit wine contained less methanol content than the maximum limit set by OIV Resolution OENO $19 / 2004(400 \mathrm{mg} / \mathrm{L}$ for red wines and $250 \mathrm{mg} / \mathrm{l}$ for white wines and rosés). Furthermore, the Food and Drug Administration (FDA) (Federal Register 58, no 204, 6088-6091, (1993)) for the Acceptable Daily Intake (ADI) of methanol in humans is 7.1 to $8.4 \mathrm{mg} / \mathrm{kg}$ body weight (bw)/day by using a safety factor of 10 . This shows that an individual weighing $70 \mathrm{~kg}$ would have to consume about 1.25 litres of wine a day with a methanol content of $400 \mathrm{mg} / \mathrm{L}$ [52]. Even though the principal metabolite of cactus pear fruit fermentation is ethanol, other alcohols like methanol could also be produced. Using pectinolytic enzymes during fruit fermentation for better solubility and splitting of pectic substances facilitates the production of galacturonic acid and methanol in the final wine. But, fruit wine production without the addition of pectinolytic enzymes readily has low (less than $(134 \mathrm{mg} / \mathrm{L})$ methanol content the presence of the enzyme [42]. Considering the negative impact on sensory properties, thermal treatment of fermenting substrate during fruit wine fermentation process assists significant decrease in the 
production of methanol (up to 60-70\%) [53]. Generally, according to the Food and Drug Administration (FDA), the current wine has acceptable methanol content $(124.4 \pm 9.5 \mathrm{mg} / \mathrm{L})$ (permissible as per FDA guideline) for human consumption.

According to the standards set by VQA Ontario, the LCBO, and the federal government, sulfur dioxide composition is dependently expressed on the residual sugar content of the grapefruit wine. That is, grapefruit wines with less than $35 \mathrm{~g} / \mathrm{L}$ residual sugar should contain a maximum limit of $50 \mathrm{mg} / \mathrm{L}$ free sulfur dioxide and $300 \mathrm{mg} / \mathrm{L}$ total sulfur dioxide. But, grapefruit wines with more than $35 \mathrm{~g} / \mathrm{L}$ residual sugar should contain a permissible limit of $70 \mathrm{mg} / \mathrm{L}$ free sulfur dioxide and $400 \mathrm{mg} / \mathrm{L}$ total sulfur dioxide. The residual sugar measured in the current cactus pear fruit wine is less than $35 \mathrm{~g} / \mathrm{L}(4.6 \mathrm{~g} / \mathrm{L})$. Free sulfur dioxide $(60.6 \mathrm{mg} / \mathrm{L})$ and total sulfur dioxide $(129.94 \mathrm{mg} / \mathrm{L})$ compositions of the current wine are in the permissible limit as compared to the grape wine standards, but it is larger than the wine produced from orange fruit juice (free sulfur dioxide $=8.2 \mathrm{mg} / \mathrm{L}$ and total sulfur dioxide $=81.5 \mathrm{mg} / \mathrm{L}$ ) [32]. Besides, the reduced amount of sulfur dioxide $\left(\mathrm{SO}_{2}\right)$ is due to the occurrence of a biochemical reaction during the fermentation process which was similarly reported in apple cider wine (from $50 \mathrm{mg} / \mathrm{L}$ to $28.77 \mathrm{mg} / \mathrm{L})$ [51]. Sulfur dioxide $\left(\mathrm{SO}_{2}\right)$ as potassium thiosulphate was used as a microbial growth inhibitor during the current fruit juice substrate preparation to inhibit the growth of some yeast species and the majority of bacteria related to wine spoilage. Due to antiseptic and antioxidant properties on the final wine, sulfur dioxide $\left(\mathrm{SO}_{2}\right)$ is the most versatile and efficient additive than other additives such as dimethyl dicarbonate (DMDC) used during winemaking. Moreover, sulfur dioxide minimizes phenolic polymerization rate and color loss during wine aging [54]. Although antiseptic and antioxidant properties of sulfur dioxide are significant, allergic responses in the fruit wine by sensitive consumers should be considered. Hence, the current fruit wine is adjusted to be in the range of international standards.

3.1.4. Sensory Quality of the Wine. Six panelists who participated in previous cactus pear fruit wine experiment and who have experience in wine drinking were chosen to examine the produced wine sensory quality in the current study. The panelists were trained to put each level of preference by ticking from the "dislike extremely" to "like extremely" which denotes to very poorly accepted and excellently accepted. The value given to these mark are from 1 (dislike extremely) to 9 (like extremely). Overall acceptability of each wine sample was expressed as average values of color, test, and flavor from each panelist's level of preference on individual wine sample. Finally, overall acceptability scores of panelists were recorded to represent the sensory quality of the produced wine. As it can be seen in Table 2, average values of overall acceptability scores of the panelist's sensory quality are greater than eight which implies the panelists liked the cactus pear fruit wine fermented with Lantana camara fruit juice. The good color of the wine could be attributed to a high concentration of phytochemicals from the added Lantana camara fruit. Color and overall acceptability of the previously produced cactus pear fruit wine by Zenebe et al. [25] have shown less acceptance by the panelists. Sensory qualities such as color and astringency of the current wine sample were mainly affected by anthocyanins, flavonols, catechins, and other flavonoids present in the fermenting substrate and additives like the Lantana camara fruit [10]. Low residual sugar content, titratable acidity, and low $\mathrm{pH}$ of the produced wine affected the sensory quality to have slight bitterness and astringency. This property is also consistent with the wine's organic acid measured using HPLC, which is predominantly citric acid. Moreover, flavor (fruity aroma) of the wine was liked by the panelists mainly due to the presence of esters in the final wine. The improved sensory qualities of the produced wine are consistent with fruit wine produced from blended fruits of pawpaw with banana [8]. Similar sensory quality score was observed in fruit wine produced from tropical bael (Aegle marmelos L.), sapota (Achras sapota Linn.) fruit wine, and apple tea wine $[36,39,40]$. In conclusion, sensory quality (overall acceptability) of the cactus pear fruit wine was improved due to the added Lantana camara fruit juice, and it was liked by the panelists.

\section{Conclusion}

In the present study, cactus pear with Lantana camara fruits fermented for six days at previously optimized fermentation process (fermentation temperature at $24.8^{\circ} \mathrm{C}, \mathrm{pH}$ at 3.4 , inoculum concentration at $10.16 \%(\mathrm{v} / \mathrm{v})$, and Lantana camara fruit juice concentration of $10.66 \%(\mathrm{v} / \mathrm{v}))$ was characterized based on prominent physicochemical fruit wine qualities. The added Lantana camara fruit juice has improved color, total phenol, sensory value, and slightly the organic acid qualities of the final wine. The final wine has revealed that sensory attributes of the wine were acceptable by the consumers. Generally, consumer's health concerning characteristics such as ethanol, methanol, $\mathrm{pH}$, and sulfite contents of the wine is under the permissible limits of international standards of fruit wine. Important nutrients, minerals, vitamins, aroma, and taste present in the cactus pear and Lantana camara fruits which have short shelf life could be addressed to consumers by fermenting them into wine. Further detailed studies on volatile acids, individual polyphenols, organic acid components, antioxidant capacity, and in vitro cytotoxicity assessment of both fruits and the produced wine are needed.

\section{Data Availability}

Basic data used to support the findings of this study are included within the article. The data related to the study concerning ANOVA and HPLC raw data including chromatogram for standard organic acid used are available from the corresponding author upon request.

\section{Conflicts of Interest}

The authors declare no conflicts of interest. 


\section{Acknowledgments}

The authors gratefully acknowledge the chemistry laboratory staff of Aksum University and Adigrat Pharmaceutical Factory (APF) quality control center for their expert support and technical assistance. This research was funded by the Research and Community Services Centre, Aksum University, Ethiopia.

\section{References}

[1] N. Chhikara, H. R. Devi, S. Jaglan, P. Sharma, P. Gupta, and A. Panghal, "Bioactive compounds, food applications and health benefits of Parkia speciosa (stinky beans): a review," Agriculture \& Food Security, vol. 7, no. 1, p. 46, 2018.

[2] N. Chhikara, R. Kaur, S. Jaglan, P. Sharma, Y. Gat, and A. Panghal, "Bioactive compounds and pharmacological and food applications of Syzygium cumini-a review," Food \& Function, vol. 9, no. 12, pp. 6096-6115, 2018.

[3] S. Kaur, A. Panghal, M. Garg et al., "Functional and nutraceutical properties of pumpkin-a review," Nutrition \& Food Science, vol. 49, 2019.

[4] B. Okeke, "Wine production from mixed fruits (pineapple and watermelon) using high alcohol tolerant yeast isolated from palm wine," Universal Journal of Microbiology Research, vol. 3, no. 4, pp. 41-45, 2015

[5] P.-J. Lee and S. Chen, "Effect of adding ball-milled achenes to must on bioactive compounds and antioxidant activities in fruit wine," Journal of Food Science and Technology, vol. 53, no. 3, pp. 1551-1560, 2016.

[6] J.-H. Lee, T. H. Kang, B. H. Um et al., "Evaluation of physicochemical properties and fermenting qualities of apple wines added with medicinal herbs," Food Science and Biotechnology, vol. 22, no. 4, pp. 1039-1046, 2013.

[7] M. Yusufu, J. Pg, and A. Sa, "Production and quality evaluation of wine from watermelon juice and ginger extract," Journal of Human Nutrition \& Food Science, vol. 6, no. 1, p. $1122,2018$.

[8] A. C. Ogodo, O. C. Ugbogu, A. E. Ugbogu, and C. S. Ezeonu, "Production of mixed fruit (pawpaw, banana and watermelon) wine using Saccharomyces cerevisiae isolated from palm wine," SpringerPlus, vol. 4, no. 1, p. 683, 2015.

[9] D. Fracassetti, P. Bottelli, O. Corona, R. Foschino, and I. Vigentini, "Innovative alcoholic drinks obtained by cofermenting grape must and fruit juice," Metabolites, vol. 9, no. $5,2019$.

[10] H. K. Yildirim, "Evaluation of colour parameters and antioxidant activities of fruit wines," International Journal of Food Sciences and Nutrition, vol. 57, no. 1-2, pp. 47-63, 2006.

[11] H. Kelebek and S. Selli, "Identification of phenolic compositions and the antioxidant capacity of mandarin juices and wines," Journal of Food Science and Technology, vol. 51, no. 6, pp. 1094-1101, 2014.

[12] A. Ljevar, "Phenolic composition, antioxidant capacity and in vitro cytotoxicity assessment of fruit wines," Food Technology and Biotechnology, vol. 54, no. 2, pp. 145-155, 2016.

[13] R. A. Chavez-Santoscoy, J. A. Gutierrez-Uribe, and S. O. Serna-Saldívar, "Phenolic composition, antioxidant capacity and in vitro cancer cell cytotoxicity of nine prickly pear (Opuntia spp.) juices," Plant Foods for Human Nutrition, vol. 64, no. 2, pp. 146-152, 2009.

[14] L. Ayed and M. Hamdi, "Manufacture of a beverage from cactus pear juice using "tea fungus" fermentation," Annals of Microbiology, vol. 65, no. 4, pp. 2293-2299, 2015.
[15] L. Jamir, V. Kumar, Y. Gat, A. Kumar, and S. Kaur, "Wine: a potential source of antimicrobial compounds," Journal of Wine Research, vol. 30, no. 3, pp. 220-237, 2019.

[16] I. Kazmi, M. Rahman, M. Afzal et al., "Anti-diabetic potential of ursolic acid stearoyl glucoside: a new triterpenic gycosidic ester from Lantana camara," Fitoterapia, vol. 83, no. 1, pp. 142-146, 2012.

[17] A. Ajiboye, O. Oyedara, D. Agboola, and O. Familola, "Evaluation of antibacterial effects and phytochemical analysis of Lantana camara linn leaf and berry extracts," European Journal of Medicinal Plants, vol. 4, no. 3, pp. 332-341, 2014.

[18] E. Tadesse, E. Engidawork, T. Nedi, and G. Mengistu, "Evaluation of the anti-diarrheal activity of the aqueous stem extract of Lantana camara Linn (Verbenaceae) in mice," BMC Complementary and Alternative Medicine, vol. 17, no. 1, p. 190, 2017.

[19] S. D. Carstairs, J. Y. Luk, C. A. Tomaszewski, and F. L. Cantrell, "Ingestion of Lantana camara is not associated with significant effects in children," Pediatrics, vol. 126, no. 6, pp. e1585-e1588, 2010.

[20] H. E. Verón, P. Gauffin Cano, E. Fabersani et al., "Cactus pear (Opuntia ficus-indica) juice fermented with autochthonous Lactobacillus plantarum S-811," Food \& Function, vol. 10, no. 2, pp. 1085-1097, 2019.

[21] L. Tesoriere, M. Fazzari, M. Allegra, and M. A. Livrea, "Biothiols, taurine, and lipid-soluble antioxidants in the edible pulp of Sicilian cactus pear (Opuntia ficus-indica) fruits and changes of bioactive juice components upon industrial processing," Journal of Agricultural and Food Chemistry, vol. 53, no. 20, pp. 7851-7855, 2005.

[22] B. Peng, Y. Lei, H. Zhao, and L. Cui, "Response surface methodology for optimization of fermentation process parameters for improving apple wine quality," Journal of Food Science and Technology, vol. 52, no. 11, pp. 7513-7518, 2015.

[23] R. Longo, J. W. Blackman, G. Antalick, P. J. Torley, S. Y. Rogiers, and L. M. Schmidtke, "Harvesting and blending options for lower alcohol wines: a sensory and chemical investigation," Journal of the Science of Food and Agriculture, vol. 98, no. 1, pp. 33-42, 2018.

[24] J. Navarrete-Bolaños, "A strategy to design efficient fermentation processes for traditional beverages production: prickly pear wine," Journal of Food Science, vol. 78, no. 10, pp. M1560-M1568, 2013.

[25] T. T. Zenebe, S. Chanukya, and M. L. Solomon, "Optimization of cactus pear fruit fermentation process for wine production," Foods, vol. 7, no. 8, p. 121, 2018.

[26] K. Gutiérrez-Moreno, "A strategy for biotechnological processes desing: prickly Pear (Opuntia ficus-indica) wine production," Chemical Engineering Transactions, vol. 20, pp. 315-320, 2010.

[27] S. S. Nielsen, "Phenol-sulfuric acid method for total carbohydrates," in Food Analysis Laboratory Manual, pp. 47-53, Springer, Boston, MA, 2010.

[28] OIV, Compendium of International Methods of Wine and Must Analysis, OIV, Paris, France, 2016.

[29] S. S. Nielsen, Food Analysis, Springer, Berlin, Germany, Fourth edition, 2010.

[30] S. Babu, K. Harinikumar, R. K. Singh, and A. Pandey, "Optimization of bioethanol production from fruit wastes using isolated microbial strains," International Journal of Advanced Biotechnology and Research, vol. 5, no. 4, pp. 598-604, 2014.

[31] J. Arrizon, C. Calderón, and G. Sandoval, "Effect of different fermentation conditions on the kinetic parameters and 
production of volatile compounds during the elaboration of a prickly pear distilled beverage," Journal of Industrial Microbiology \& Biotechnology, vol. 33, no. 11, pp. 921-928, 2006.

[32] H. Kelebek, S. Selli, A. Canbas, and T. Cabaroglu, "HPLC determination of organic acids, sugars, phenolic compositions and antioxidant capacity of orange juice and orange wine made from a Turkish cv. Kozan," Microchemical Journal, vol. 91, no. 2, pp. 187-192, 2009.

[33] Y.-Y. Zhan, Y. Zhang, Q.-M. Li, and X.-Z. Du, "A novel visible spectrophotometric method for the determination of methanol using sodium nitroprusside as spectroscopic probe," Journal of the Chinese Chemical Society, vol. 57, no. 2, pp. 230-235, 2010.

[34] OIV, "Compendium of international methods of wine and must analysis," in Method OIV-MA-AS312-01A, International Organisation of Vine and Wine, Paris, France, 2016.

[35] OIV, Compendium of International Methods of Wine and Must Analysis, International Organisation of Vine and Wine, Paris, France, 2017.

[36] V. Kumar, V. K. Joshi, G. Vyas, N. Thakur, and N. Sharma, "Process optimization for the preparation of apple tea wine with analysis of its sensory and physico-chemical characteristics and antimicrobial activity against food-borne pathogens," Nutrafoods, vol. 15, pp. 111-121, 2016.

[37] E. H. Soufleros, I. Pissa, D. Petridis et al., "Instrumental analysis of volatile and other compounds of Greek kiwi wine; sensory evaluation and optimisation of its composition," Food Chemistry, vol. 75, no. 4, pp. 487-500, 2001.

[38] S. K. Panda, M. R. Swain, S. Singh, and R. C. Ray, "Proximate compositions of a herbal purple sweet potato (Ipomoea batatasl.) wine," Journal of Food Processing and Preservation, vol. 37, no. 5, pp. 596-604, 2013.

[39] S. K. Panda, U. C. Sahu, S. K. Behera, and R. C. Ray, "Bioprocessing of bael (Aegle marmelos L.) fruits into wine with antioxidants," Food Bioscience, vol. 5, pp. 34-41, 2014.

[40] S. Panda, D. U. Sahu, D. S. Behera, and R. Ray, "Fermentation of Sapota (Achras sapota Linn.) Fruits to Functional Wine," Nutrafoods, vol. 13, no. 4, pp. 179-186, 2014.

[41] S. K. Panda, S. K. Behera, X. Witness Qaku et al., "Quality enhancement of prickly pears (Opuntia sp.) juice through probiotic fermentation using Lactobacillus fermentum-ATCC 9338," LWT, vol. 75, pp. 453-459, 2017.

[42] L. V. A. Reddy and O. V. S. Reddy, "Production and characterization of wine from mango fruit (Mangifera indica L.)," World Journal of Microbiology and Biotechnology, vol. 21, no. 8-9, pp. 1345-1350, 2005.

[43] G. Petzold, P. Orellana, J. Moreno, E. Cerda, and P. Parra, "Vacuum-assisted block freeze concentration applied to wine," Innovative Food Science \& Emerging Technologies, vol. 36, pp. 330-335, 2016.

[44] S. C. Cunha, J. O. Fernandes, M. A. Faria, I. M. P. L. V. O. Ferreira, and M. A. Ferreira, "Quantification of organic acids in grape musts and port wines cuantificación de ácidos orgánicos en mostos $\mathrm{Y}$ vinos de oporto cuantificación de ácidos orgánicos en mostos $\mathrm{E}$ viños de porto," Ciencia Y Tecnologia Alimentaria, vol. 3, no. 4, pp. 212-216, 2002.

[45] E. O. Sousa, J. B. T. Rocha, L. M. Barros, A. R. C. Barros, and J. G. M. Costa, "Phytochemical characterization and in vitro antioxidant properties of Lantana camara L. and Lantana montevidensis Briq," Industrial Crops and Products, vol. 43, pp. 517-522, 2013.

[46] W. Tchabo, Y. Ma, E. Kwaw, H. Zhang, and X. Li, "Influence of fermentation parameters on phytochemical profile and volatile properties of mulberry (Morus nigra) wine," Journal of the Institute of Brewing, vol. 123, no. 1, pp. 151-158, 2017.

[47] R. Scherer, A. C. P. Rybka, C. A. Ballus, A. D. Meinhart, J. T. Filho, and H. T. Godoy, "Validation of a HPLC method for simultaneous determination of main organic acids in fruits and juices," Food Chemistry, vol. 135, no. 1, pp. 150-154, 2012.

[48] B. S. Chidi, D. Rossouw, A. S. Buica, and F. F. Bauer, "Determining the impact of industrial wine yeast strains on organic acid production under white and red wine-like fermentation conditions," South African Journal of Enology and Viticulture, vol. 36, no. 3, pp. 316-327, 2015.

[49] J. L. Aleixandre-Tudo, A. Buica, H. Nieuwoudt, J. L. Aleixandre, and W. du Toit, "Spectrophotometric analysis of phenolic compounds in grapes and wines," Journal of Agricultural and Food Chemistry, vol. 65, no. 20, pp. 40094026, 2017.

[50] V. Joshi, V. Kumar, and A. Kumar, "Physico-chemical and sensory evaluation of wines from different citrus fruits of Himachal Pradesh," International Journal of Food and Fermentation Technology, vol. 2, no. 2, pp. 145-158, 2012.

[51] V. K. Joshi, R. Sharma, V. Kumar, and D. Joshi, "Optimization of a process for preparation of base wine for cider vinegar production," Proceedings of the National Academy of Sciences, India Section B: Biological Sciences, vol. 89, no. 3, pp. 10071016, 2019.

[52] G. Hodson, E. Wilkes, S. Azevedo, and T. Battaglene, "Methanol in wine," BIO Web of Conferences, vol. 9, Article ID 02028, 2017.

[53] U. Miljić, V. Puškaš, and V. Vučurović, "Investigation of technological approaches for reduction of methanol formation in plum wines," Journal of the Institute of Brewing, vol. 122, no. 4, pp. 635-643, 2016.

[54] M. C. Santos, C. Nunes, J. A. Saraiva, and M. A. Coimbra, "Chemical and physical methodologies for the replacement/ reduction of sulfur dioxide use during winemaking: review of their potentialities and limitations," European Food Research and Technology, vol. 234, no. 1, pp. 1-12, 2012. 


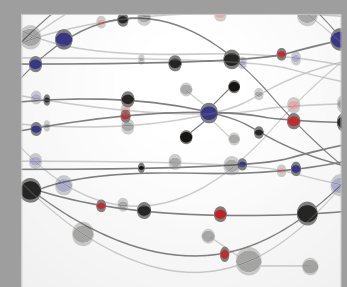

The Scientific World Journal
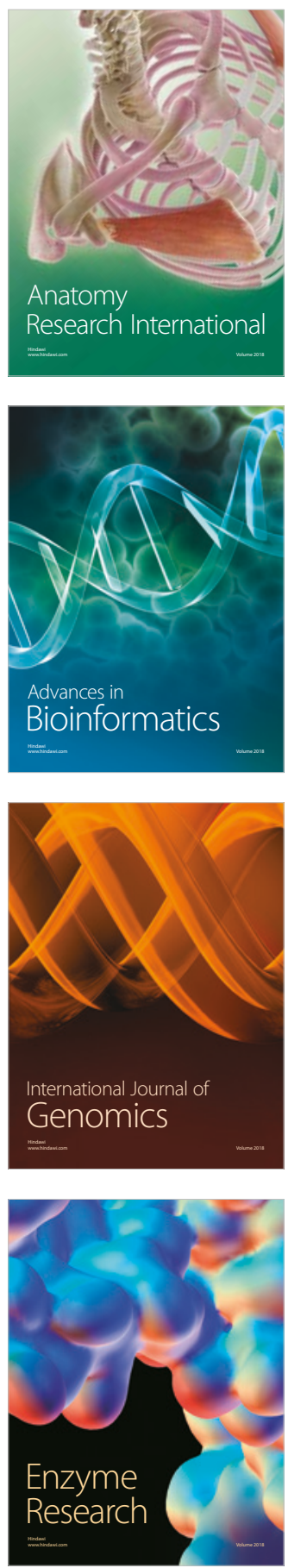
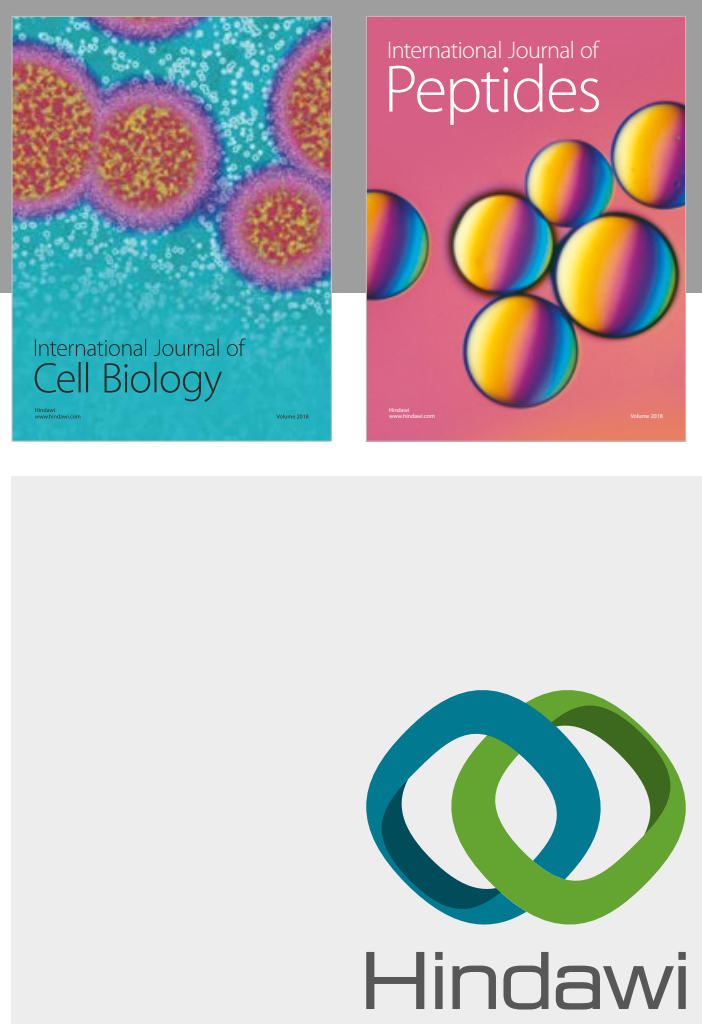

Submit your manuscripts at

www.hindawi.com
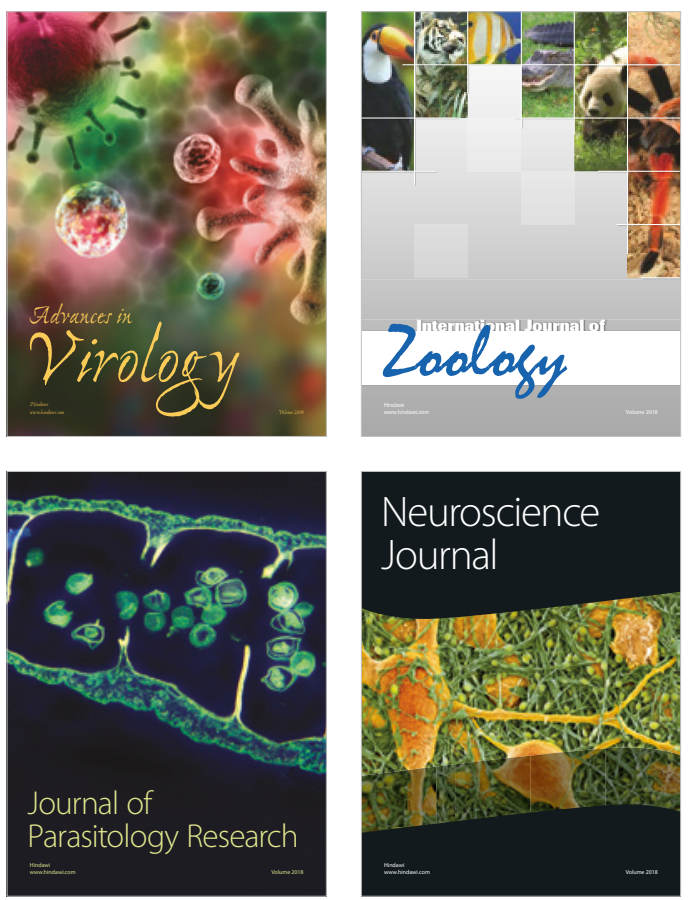
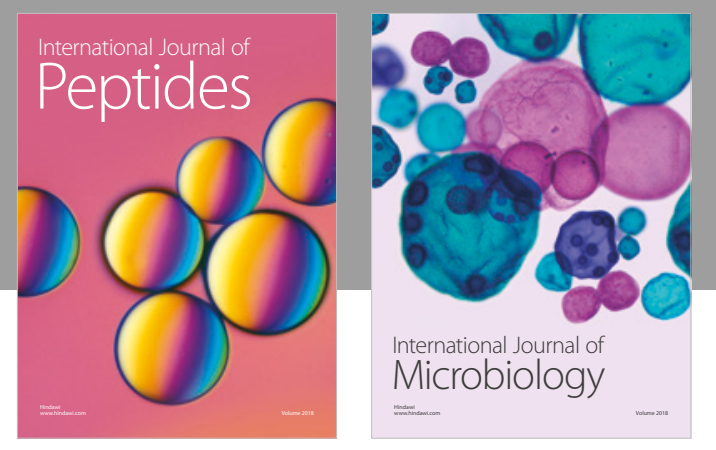

nternational Journal of Microbiology
Journal of
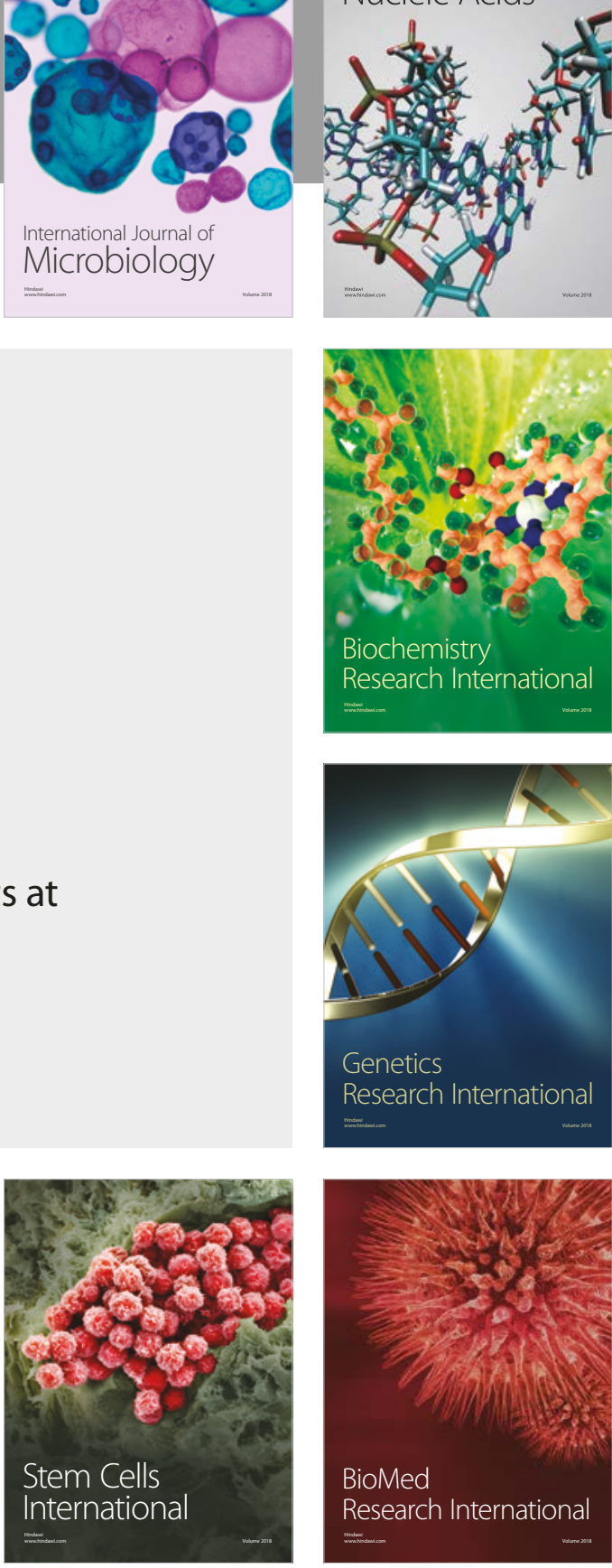
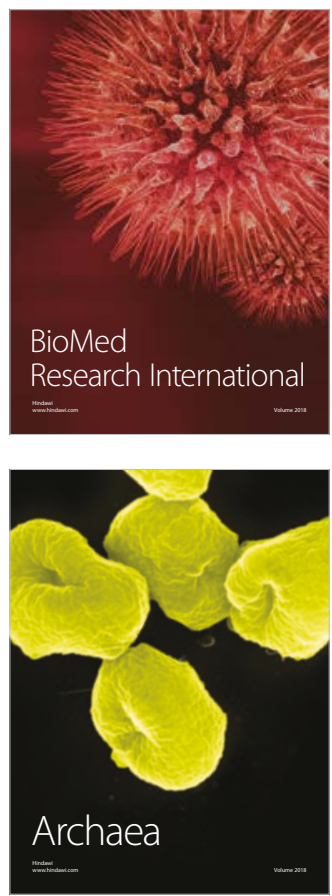